\title{
Positive language transfer of causative verbs in Chinese-Portuguese simultaneous interpretations
}

\author{
Transferência positiva dos verbos causativos na interpretação simultânea de chinês-português
}

\author{
Sun Yuqi \\ Macau University of Science and Technology - Taipa, Macau, China
}

\begin{abstract}
This study addresses the question of whether there is positive language transfer through causative verbs in Chinese-Portuguese Simultaneous Interpreting, and in which aspects this transfer is more likely to occur. The paper begins by providing a brief discussion of language transfer and the causative construction in Chinese and Portuguese. Then, we present the methodology, in which 10 speeches delivered by Chinese leaders in intercultural contexts and their simultaneous interpretations are transcribed and analyzed. The results show that both Chinese source texts and Portuguese interpretations present a high percentage of causative verbs, and more than half of the data can be interpreted as positive transfer. We found that positive language transfer occurs and plays a very important role in Chinese-Portuguese Simultaneous Interpreting and may help interpreters facilitate information processing in order to achieve better performance.
\end{abstract}

Keywords: Positive transfer; Causative verbs; Simultaneous interpretation; Chinese and Portuguese.

Resumo: O estudo procura responder se a transferência positiva de língua existe através dos verbos causativos na Interpretação Simultânea de Chinês-Português, e em que aspectos tal transferência ocorre mais frequentemente. $\mathrm{O}$ artigo começa fornecendo uma breve discussão sobre a transferência linguística e a construção causativa em chinês e português. Passa à parte metodológica, na qual são transcritos e analisados 10 discursos proferidos por líderes chineses em contextos interculturais e suas interpretações simultâneas. Os resultados mostram que tanto os textos em chinês quanto as interpretações em português apresentam uma alta porcentagem de verbos causativos, e mais da metade dos dados é interpretada através da transferência positiva. Verifica-se que a transferência positiva existe e desempenha um papel muito importante na Interpretação Simultânea de Chinês-Português, e a referente estratégia pode ajudar os intérpretes a facilitar o processamento da informação, assim para conseguir um melhor desempenho.

Palavras-chave: Transferência positiva; Verbos causativos; Interpretação simultânea; Chinês e Português.

\section{Introduction}

Simultaneous Interpreting (SI), which serves as a bridge for intercultural communication, has received a great deal of attention from scholars on translation and interpretation as well as from the general public. Thanks to this breakthrough and to the development of modern technology, SI has become one of the most widely adopted means of interpreting in international conferences, business meetings, among other occasions. This kind of interpreting activity requires the coordination of listening, comprehension, memorization and production at the same time. Compared with consecutive interpreting, SI is less time consuming and is viable in multi-lingual conferences. Due to the brief time lag, SI requires an interpreter to deliver the message in the target language as quickly as he or she can formulate it, while the source language speaker speaks continuously. Over the years, research has been carried out by scholars from China and abroad to figure out effective means to improve SI.

Traditionally, the biggest obstacle to SI has been attributed to the fact that interpreters or SI practitioners apply their L1 knowledge subconsciously when reproducing in the target language, or L2, the meaning expressed in the source language speech. As a result, language transfer has been studied by many scholars. 
And the role of L1 has been discussed heatedly. Since the 1980s, a neutral perspective emerged and it helped people rethink the role of language transfer within a cognitive framework.

In the literature (see DE ANGELIS \& DEWAELE 2011, SINGLETON 2012, 2015), negative language transfer has attracted more attention from scholars. One of the reasons is that negative transfer is more easily observed when errors occur in the production of L2. These errors attract attention from researchers instead of the correct utterances. Therefore, some people believe that trying to forget the $\mathrm{L} 1$ is a reasonable and effective way to learn the L2 well and claim that it will facilitate simultaneous interpreters' fluency and accuracy. Moreover, both researchers on L2 and L2 learners have reached a consensus that the structure of Chinese differs from that of Western languages, such as Portuguese, and this difference is regarded as the biggest obstacle to Chinese students learning Portuguese. Whenever we hear a high quality SI, we infer that the simultaneous interpreter has successfully avoided the influence exerted by Chinese when undertaking a task of Chinese-Portuguese (C-P) SI.

However, studies such as those of cognitive processing (PARADIS, 2009), mind-language relations (BARDEL \& FALK, 2012), L1 roles (LIGHTBOWN, 2006) and bilingual working modes (CENOZ, 2013), show that it is inevitable that $\mathrm{L} 1$ always produces interventions in the process of learning or using an L2. When language transfer occurs, we can observe both positive language transfer and negative language transfer at the same time. Although research and theories on positive language transfer are limited in both quantity and quality, we argue that positive language transfer is of great importance and deserves more attention from SI trainees, practitioners and trainers.

In this paper, language transfer specifically refers to the role that Chinese as an L1 plays in the production of Portuguese as an L2. In particular, we discuss causative constructions, which are the linguistic representations of causality, as in "Estudar faz-me feliz" (Studying makes me happy). Causative constructions denote events in which the causer - estudar (studying) performs or at least initiates something, and the caused events in which the causee - me (me) carries out an action or undergoes a change of condition or state-feliz (happy) as a result of the causer's action. Thus, the causing events serve as the external factors of the change, while the caused events are the outcomes. The causative constructions can be formalized as [x ACT] CAUSE [y BECOME $<$ STATE $>$ ] (CHANG \& ZHENG, 2015). This study addresses the issue of whether there is positive language transfer in causative verbs of C-P SI and in which aspects this positive language transfer is more likely to occur? First, however, we will take a closer look at the concept of language transfer and causative constructions between Chinese and Portuguese.

\section{Language transfer}

The word "transfer" has had many specialized uses in different areas. Even in linguistics, the technical meanings of transfer are far from uniform. In a book written by Gass and Behney (2013), they find that there are more than 30 ways of defining the term "language transfer", which shows both the significance of the role of language transfer and scholars' ceaseless exploration on this issue. In their book, there is a simple and precise definition of language transfer based on their years of research into this phenomenon, which has been widely recognized:

Language transfer refers to the use of the first language (or other languages known) in a second-language context. When the resulting second-language form is incorrect, it is regarded as interference (also negative transfer). Conversely, if resulting in a target-like second-language form, it is considered as facilitation (also positive transfer) (Gass \& Behney, 2013, p.47).

The definition deliberately includes "other languages known" because there are many cases of people learning not only a second language (L2) but also a third (L3). For example, in China, the majority of Chinese students who study Portuguese in higher education have English as their L2, and so similarities and differences between English and Portuguese as well as similarities and differences between Chinese and Portuguese might affect a learner's acquisition of the L3 (see DE ANGELIS \& DEWAELE, 2011; GABRYŚ-BARKER, 2012; SUN, 2015). Even when only two languages are involved, the language transfer or cross-linguistic influence can be manifested in different ways.

Traditionally, the phenomenon tended to be represented as negative, to be resisted or remedied (see DE ANGELIS \& DEWAELE 2011, SINGLETON 2012, 2015), and this view continued to prevail through the following decades (see VILOMEC 1963, JAMES 1971), during which contrastive analysis dominated applied linguistics. At this time, contrastive analysis drew heavily on the psychological theory of behaviorism, thanks to which positive transfer came to be fully recognized (see LADO, 1957; LIGHTBOWN \& SPADA, 2013).

When "language transfer" (also termed "linguistic transfer") is discussed, not only are languages analyzed, but their representations are also looked into as well. More specifically, language transfer occurs "between bilingual representations" (GASS \& BEHNEY, 2013, p. 37), which can be seen in the following figure: 


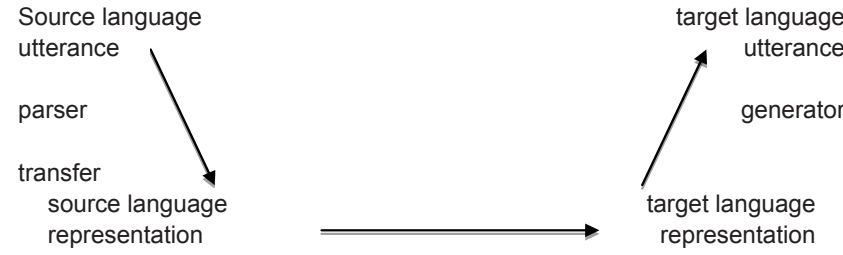

Figure 1. Language transfer and representation (GASS \& BEHNEY, 2013, p. 37)

Lightbown (2006:113) observes, "Most of the mistakes which second language learners make are due to interference from their L1 and the transfer of patterns from the native language is one of the causes for errors in the target language". Moreover, she also suggests that language transfer is universal when explaining L2 learning (LIGHTBOWN \& SPADA, 2013). However, Lourdes Ortega explains the complex issue of L1 influence on L2 learning and describes language transfer as "crosslinguistic influences" (ORTEGA, 2008, p. 190). The following figure shows a widely-recognized classification of language transfer by Douglas Brown (2006, p. 109):

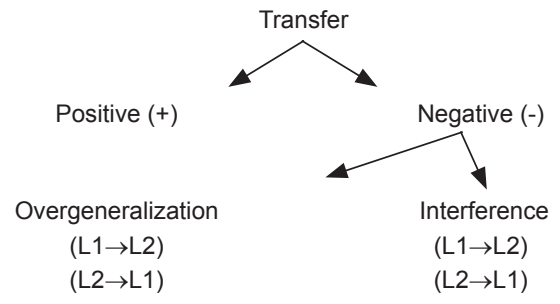

Figure 2. Language transfer and interference

The figure above shows, once again, the fact that negative language transfer draws more attention in the literature, and the apparent feature of language transfer is simplification (COOK, 2008; ISHIHARA, 2010, LIGHTBOWN \& SPADA, 2013) and overgeneralization (YU, 2011; PASQUARELLA, 2011).

However, in recent years, more and more scholars have realized the importance of positive language transfer and hold that positive language transfer can make learning easier. Ellis regards positive language transfer as facilitation and asserts, "it is evident not so much in the total absence of certain errors, as would be expected on the basis of behaviorist notions of positive transfer, but rather in a reduced number of errors and also in the rate of learning" (ELLIS, 1997:30). NITSCHKE (2010) shows that the L1 affects the capacity of comprehension during L2 learning. Littlemore (2009) focuses on the extent to which learners can autonomously guess the meaning of metaphors. On the syntactic level, Breustedt (2009) demonstrates that L1 always exerts some influence on L2 learning. Moreover, Larsen-Freeman (2003) reaches the same conclusion through observations of L2 learners' learning of English grammar. According to Gass and Behney (2013), language transfer helps us to see the grammatical elements that are universal in all human languages. From the perspective of being a teacher, De Bot (2006) discusses the amount of words learners have already learned before they begin to learn the Target Language (TL) and its impact on learning new words.

As for the studies in simultaneous interpreting, especially the interpretation between Chinese and Western languages, most of them concerning language transfer are limited to negative language transfer between Chinese and English.

Wang Lidi (2009) studies interpreting skills and techniques and applies basic notions of schema theory to the process of interpreting and translating. He implies that a qualified interpreter can produce accurately and fluently in the TL without interference of the source language (SL). Bao (2011) writes that interpreters get information from the SL and then process the information in their cognitive systems, which should minimize the interference from the SL. Hu (2013) claims that the fundamental purpose of interpretation is to achieve a mutual understanding for both ends of communication and interpreters should keep L1 transfer away from interpreting.

However, only a few scholars note that positive language transfer indeed plays a significant role in SI and L2 learning. Wang (2002) believes that language transfer from $\mathrm{L} 1$ cannot be avoided and positive language transfer should be used in L2 translation. Yu (2009, p. 103) believes that "positive transfer occurs in many levels between the Chinese and English language, ranging from pronunciation, word order, writing and discourse". Moreover, empirical studies conducted by Guo (2007) and Wen (2011), using the method "Think Aloud Protocols" with Chinese subjects who have different L2 proficiencies, point to the significant role of L1 when L2 learners decide to use certain words or phrases in their English composition. Wen (2011) concluded that L1 does serve as the medium for logical judgment, analysis and deduction in target language output.

To the best of our knowledge, no studies have been conducted to examine the language transfer from Chinese (L1) to Portuguese (L2) during SI, much less studies that take into account causative constructions. The present study aims to help fill the gap and achieve some understanding of how Chinese speakers with a high proficiency in Portuguese manifest in SI. Before our discussion of the issue, however, a contrastive analysis of Causative Constructions in Chinese and Portuguese is necessary. 


\section{Chinese and Portuguese Causative Constructions}

According to Chang and Zheng (2015), causative verbs can be classified into four categories according to their morphological features:

1. Causative light verbs or auxiliary verbs, such as fazer (make), causar (cause), deixar (let) in Portuguese; and 使 (make), 让 (let), 令 (cause) in Chinese. As for this category, Chinese and Portuguese correspond closely. For example:

(1) 困难 使人成长。 difficulty make person grow

(2) A dificuldade faz um homem crescer. the difficulty make a man grow.

Difficulty makes a man grow.

2. Affixed causative verbs, including words with bound morphemes, expressing causation with prefixes or suffixes, such as humanizar (humanize), simplificar (simplify), esfriar (cool), engordar (fatten) in Portuguese; and简化 (simplify), 美化 (beautify) in Chinese.

(3) 艺术 美化 生活。

art beautify life

(4) A arte embeleza a vida.

the art beautifies the life

Art beautifies life.

While Portuguese has a large repertory of affixed causative verbs, Chinese is morphologically impoverished, having few affixed causative verbs (CHANG \& ZHENG 2015). Although there is a causative suffix 化 in Chinese, which is similar to Portuguese -izar and -ficar, its application is restricted to a handful of adjectives and nouns.

3. Converted causative verbs, which are verbs converted (or zero-derived) from nouns or adjectives. This type of causative verbs is quite common in Chinese, such as 丰富 (rich), 充实 (full), but not in Portuguese. In addition, these verbs in Chinese are similar to the Portuguese verbs with prefixes es- and en-, which belong to the previous category. As in the examples below.

(5) 这些 经历丰富了他的人生。

these experience rich-le ${ }^{1}$ his life.

The experiences enriched his life.

\footnotetext{
There are two $\mathrm{s}$ (le) in Chinese. The $了$ here is a perfect aspectual marker used directly after the transitive verbs to show the action or the change that has been done, as in (5). The other $l e$ is a particle used at the end of the sentence or the pause in the middle to show the change of the status or to indicate a new situation as in (8).
}

4. Compound causative verbs, which consist of two or more than two parts, one expressing an action and the other one introducing the result of that action. The result part is always emphasized. As in the Chinese verb 击败 (beat), the first morpheme 击 (hit or attack) is a verb initiating an action, and the second morpheme 败 (defeated) is the result of the action 击. Moreover, in a Portuguese example, the verbs adoentar is composed of doente (sick), which introduces the result, and -entar, which is associated with the action and the idea of a motivation-causal of the primitive. For Caetano (2012), in Portuguese, these verbs usually end with morphemes such as -ar,-ear, -entar e-antar etc., as shown in the examples.

(6) 他打碎了杯子。

he break-le cup

(7) Ele quebrou o copo.

he broke the cup

He broke the cup.

Another common pattern in Chinese that shows the emphasis of result in Chinese causative construction is a ba-construction, in which, the sentence structure is changed according to the addition of the free morpheme 把.

(8) 他把杯子打碎了 1 。

he ba cup break-le

He broke the cup.

Although the examples given so far might suggest that the syntactic and morphological correspondences between Chinese and Portuguese are usually straightforward, this is not always the case.

Portuguese has a rather large repertory of affixed causative verbs; Chinese is morphologically impoverished, having few affixed causative verbs. Therefore, when Portuguese affixed verbs such as engordar (fatten) do not have morphologically close counterparts in Chinese, the corresponding Chinese can be a periphrastic construction, a ba-construction or a lexical causative, all three patterns being possible as translations of the sentence a carne engorda o cachorro (The meat fattens the dog).

(9) 肉使狗变胖。 meat make dog become fat

(10) 肉吃胖了那条狗。 meat fatten-le that-CL dog

(11) 肉把狗吃胖了。 meat ba dog fatten-le

Moreover, causative constructions in Chinese are normally formed syntactically with the help of causative 
light verbs, or lexically with compound causative verbs. In contrast, Portuguese causative constructions are normally formed either with bound morphemes, which function as causative affixes, or with causative light verbs. In written texts, it is not easy to find correspondences of the same type of causative construction between the two languages. However, whether this correspondence is equally rare in SI will be examined in the next stage of our research.

\section{Methodology}

The research data range from economic, political, and social intercultural contexts, such as Ministerial Conference of Forum Macao (2015), President's New Year Messages (from 2013 to 2017) and Commemoration of the 70th Anniversary of World Anti-Fascist War (2015). They are all representatives of momentous intercultural occasions. Speeches by Chinese leaders in intercultural contexts serve as a window for the outside world and present China's national image. Therefore, interpreters who are chosen to carry out simultaneous interpreting on these occasions must have proficiency in both Chinese and Portuguese.

All the data for this research were collected from open access sources. Some of the SI materials were downloaded from official websites of the central people's government of China and Teledifusão de Macau ${ }^{2}$. Moreover, some of them were downloaded from information-sharing websites such as Youtube, with good voice quality.

Ideally, all data analyzed in studies of language transfer should be obtained from natural observation in which participants produce language authentically and are not aware that they are being observed. All the videos were recorded by professional technicians on the spot, which ensures its validity and efficiency.
The simultaneous interpreting materials were transcribed into texts by dictation and the transcribed texts were recorded in .txt files due to the fact that text type can be commonly applied to almost all software. Then, the total numbers of Portuguese and Chinese words in these texts were calculated in WordSmith (SCOTT, 2010). The numbers can be seen in Table 1 (bellow).

In the next step, all the texts were imported into a software named ParaConc (BARLOW, 2008), which automatically adjusted texts in alignment. In the program, texts of speeches by Chinese leaders paralleled transcribed texts of simultaneous interpreting of those speeches by setting the timeline, which enabled a wide range of investigations and helped us investigate linguistic similarities between source Chinese texts and target Portuguese ones. If some words or phrase stand out, they can be marked for analyzing positive language transfer in such aspects as causative verbs.

Quantitative analyses were conducted for concordance of parallel bilingual texts, aiming to examine existence and frequency of positive language transfer in SI. In the next section, linguistic details of quantitative analyses and research findings are explained and discussed.

\section{Results and discussion}

In this section, data are analyzed and discussed to report the findings from quantitative analyses of SI materials selected for this study in aspects of causative construction. Upon conducting quantitative analyses, two tables are presented to point out the frequency of positive language transfer in Chinese-Portuguese SI. Examples from the data are analyzed in detail throughout this section to argue for the claim that positive language transfer should be taken advantage of in C-P SI.

Table 1. Word and Sentence occurrences in the Chinese and Portuguese texts

\begin{tabular}{cccccc}
\hline \multirow{2}{*}{ Texts } & \multicolumn{2}{c}{ Chinese } & & \multicolumn{2}{c}{ Portuguese } \\
\cline { 2 - 3 } \cline { 5 - 6 } V1 & Word occur. & Sentence occur. & & Word occur. & Sentence occur. \\
V2 & 432 & 44 & 119 & 1,053 & 62 \\
V3 & 1,518 & 59 & & 3,752 & 236 \\
V4 & 635 & 66 & 886 & 41 \\
V5 & 791 & 77 & & 1,117 & 90 \\
V6 & 879 & 131 & & 3,996 & 87 \\
V7 & 1,422 & 75 & 3,144 & 199 \\
V8 & 802 & 39 & 1,698 & 106 \\
V9 & 411 & 43 & 1,054 & 58 \\
V10 & 520 & 102 & 1,281 & 78 \\
Total & 969 & 755 & 2,001 & 105 \\
\hline
\end{tabular}

\footnotetext{
2 Teledifusão de Macau: $<$ http://www.tdm.com.mo/index.php>.
} 
Table 2. Number of different types of causative construction in Chinese and Portuguese texts.

\begin{tabular}{lcccc}
\hline \multirow{2}{*}{ Causative verb types } & \multicolumn{2}{c}{ Chinese (Source) } & \multicolumn{2}{c}{ Portuguese (Target) } \\
\cline { 2 - 5 } & No. of Sentence & Frequency & No. of Sentence & Frequency \\
\hline Light verbs & 64 & $48.12 \%$ & 67 & $48.55 \%$ \\
Affixed verbs & 7 & $5.26 \%$ & 58 & $42.03 \%$ \\
Converted verbs & 9 & $6.76 \%$ & 0 & 0 \\
Compound verbs & 53 & $39.85 \%$ & 13 & $9.42 \%$ \\
Total & 133 & $100 \%$ & 138 & $100 \%$ \\
\hline
\end{tabular}

The distribution of four types of causative construction in Chinese source texts and Portuguese target texts can be seen in Table 2 .

The table above shows the overall situation of the use of four categories of causative verbs in the Chinese source texts and Portuguese interpreted texts. As already noted in Table 1 in the previous section, there are a total of 755 sentences in Chinese texts and 1,062 sentences in Portuguese interpretations. The difference was quite large, and it shows a fact that in SI, there is no correspondence between the number of sentences used in Chinese source texts and Portuguese target texts. However, as for the numbers of causative constructions, the difference between Chinese texts and Portuguese interpretations becomes much smaller. There are 133 occurrences in Chinese and 138 occurrences in Portuguese. We can deduce that most of the sentences that contain causative constructions in Chinese were interpreted directly in Portuguese.

Moreover, the percentage of causative verbs also surprised us. In all speeches, $17.62 \%$ (133/755) of sentences in Chinese and $12.99 \%$ (138/1062) of sentences in Portuguese present causative verbs. Therefore, the causative construction is a very important linguistic aspect in both SI and the acquisition of Portuguese. It should also be noted that in addition to causative verbs, there are still 27 pieces of data with the ba-construction, which are all interpreted in Portuguese with sentences containing causative verbs.

In Chinese texts, the most used causative construction types are light verbs (48.12\%) and compound verbs $(39.85 \%)$, differing from the interpreted texts in Portuguese, which present a higher frequency in the use of light verbs (48.55\%) and affixed verbs (42.03\%). Only nine occurrences of converted verbs were found in Chinese speeches, which did not have corresponding data of the same type of causative verbs in Portuguese interpretations, and seven occurrences of affixed verbs were found with the morpheme - 化. Furthermore, through a more detailed analysis, we observed how positive transfer, considering the same type of verbs used both in the source text and in the target text, occurs in the data.
Table 3. Percentage of different types of language transfer in causative construction.

\begin{tabular}{lcc}
\hline Causative verb types & $\begin{array}{c}\text { No. of positive } \\
\text { transfers }\end{array}$ & Percentage \\
\hline Causative light verbs & 57 & $93.44 \%$ \\
Affixed causative verbs & 7 & $100 \%$ \\
Converted causative verbs & 0 & 0 \\
Compound causative verbs & 7 & $13.2 \%$ \\
Total & 71 & $53.38 \%$ \\
\hline
\end{tabular}

The percentages in Table 3 reflect cases of positive language transfer in each type of causative verbs in relation to the occurrences of referring causative construction in Chinese texts, which can be presented in the following formula.

Percentage $=\frac{\text { (No.of Positive Tranfers) }}{(\text { No.of causative sentences in Chinese so }}$

From Table 3, we can see that $53.38 \%$ of the causative verbs were interpreted through positive transfer, that is, from the same category of causative construction. The results indicate that positive transfer plays an important role in C-P SI. The following are examples of each category of causative verbs in C-P SI, which may support our understanding of the phenomenon.

\section{Causative light verbs}

In this category, the highest frequency of positive transfers is presented. Of a total of 64 light verb occurrences, $93.44 \%$ were interpreted through the same structure. For example:

(a) 这一伟大胜利使中国人民赢得了世界爱好和平 人民的尊敬。

This one great triumph make Chinese people win le world love Peace people's respect

(b) Esta grande vitória faz o povo chinês ganhar o respeito dos povos do mundo que amam a paz. (interpretation) This great triumph make the people Chinese win the respect of people of world that love the peace. 
This great triumph makes the Chinese people win the respect of all peace-loving people around the world.

Although this sentence can be restructured in other ways, which may be shorter and simpler in interpretation, the interpreter has chosen the closest structure to the source text.

There are also some instances where language transfer is not presented. As shown in examples (c) and (d), instead of using light verbs, the interpreter applies prepositional phrases to express the purpose of the action.

(c) 全党全国各族人民要团结一心 ... 让国家发展 和人民生活一年 比一年好。

all-party all-country every-ethnic people should unit one-hart ... make country develop and people life oneyear than one-year good

(d) Todo o Partido e o povo de todas as etnias devem ser unidos como um só... a fim de materializar um melhor desenvolvimento do país e uma melhor vida do povo a cada ano. (interpretation)

all the party and the people of all the ethnicities must be united as one only... in order to materialize a better development of country and a better life of people by each year

All party members and people of all ethnic groups in the country must be united as one... making China a better country year by year and constantly improving people's lives.

\section{Affixed causative verbs}

Even if there are only seven occurrences of affixed causative verbs in Chinese, all of them are interpreted based on positive transfer.

(e) 我们要继续全面深化改革。

we will continue comprehensively deepen reform

(f) Vamos continuar aprofundar de maneira abrangente a reforma. (interpretation)

will-(we) continue deepen by manner comprehensive

We will continue to comprehensively deepen the reforms.

\section{Converted causative verbs}

In this category, there are no occurrences in Portuguese, due to its morphological linguistic feature. However, the distribution of causative constructions in the interpreted texts is very clear. Among 53 compound causative verbs in Chinese, 45 are interpreted through affixed causative verbs, which shows a trend of the transfer strategy. （g）我们必须端正工作作风。

we must correct work style

(h) Temos que endireitar o estilo de trabalho. (interpretation)

must-(we) straighten the style of work

We must improve our work style.

\section{Compound causative verbs}

The compound causative verb is the second most applied category in Chinese speeches. As shown in (i) and (k), the word 打破 is composed of 打 (break) and 破 (broken) and the word确定is composed of 确 (define) and 定 (definite). However, this type of verb does not present many correspondences in Portuguese. Therefore, there were not many transfers from this category of causative verbs. The percentage of positive transfers such as (j), is only $13.2 \%$. In addition, the other occurrences in Chinese are generally interpreted by non-clearly causative structures such as (1).

(i) 我们应该积极打破固有模式。 we should active break inherent model

(j) Devemos quebrar ativamente o modelo inerente. (interpretation)

should-(we) break actively the model inherent

(k) We should actively break the inherent model. 这一年, 我们确定了烈士纪念日。

This one-year, we definit-le martyr memorial day

(1) Neste ano, definimos o Dia de Memória aos Mártires. (interpretation)

In-this year, definit-(we) the day of memory to-the-(pl) Martyrs

In this year, we established the Commemorative Day of Martyrs.

\section{Conclusion}

The impact of the L1 on L2 acquisition occurs on different linguistic levels, which has been explored and analysed in various models over the past decades. Studies on the social level of language contact and bilingualism also suggest that the L2 can encroach on the structure of L1 in systematic ways. For instance, Vivian Cook (2003) believes that "L2 learners differed in a variety of perspectives including vocabulary, syntax, pragmatics, cognition, and using a variety of linguistic and psychological models" (2003, p. 144). Therefore, we aimed to discuss positive language transfer and its frequency of causative verbs in research data.

Through the case studies of 10 speeches delivered by Chinese leaders in intercultural contexts and their simultaneous interpretations, we have found that positive 
language transfer does exist and plays a very important role in C-P SI. Among the four categories of causative verbs, the one that presents the most positive transfers is the causative light verb, followed by affixed causative verbs and compound causative verbs. Although there are no occurrences of converted causative verbs in Portuguese, the interpretation of this type of causative construction from Chinese to Portuguese shows a clear trend in language transfer.

One major difficulty in SI is the high delivery rate and the intense information of the source language. As one of the strategies for SI, positive language transfer can help lessen interpreters' cognitive load and facilitate the information processing so as to help achieve better performance in SI. We hope that the present study may provide some helpful recommendations for the use of positive language transfer in C-P SI.

\section{References}

BAO, G. Kouyi Lilun Gaishu. Beijing: China Translation Corporation, 2011

BARDEL, C.; FALK, Y. The L2 status factor and the declarative/ procedural distinction. In: AYOUN, D.; DEKEYSER, B. (Ed). Third Language Acquisition in Adulthood. Amsterdam/ Philadelphia: John Benjamins, 2012. p.61-78.

BARLOW, M. Parallel Texts and Corpus-Based Contrastive Analysis. In: GONZÁLEZ M.; MACKENIZIE, J. and ÁLVAREZ, E. (Ed.). Current Trends in Contrastive Linguistics: functional and cognitive perspectives. Amsterdam: John Benjamins, 2008. p. 101-121.

BREUSTEDT, B. Prefabricated input in language learning. Saarbrucken: VDM Publishing House, 2009.

BROWN, D. Principles of language learning and teaching. USA: Pearson Education, 2006.

CENOZ, J. The influence of bilingualism on third language acquisition: Focus on multilingualism. Language Teaching, v. sem, n. 1, p. 71-86, 2013.

CHANG, H.; ZHENG, L. The role of L1 in the acquisition of Chinese Causative Constructions by English-Speaking learners. In YU, L.; ODLIN, T. (Ed.). New Perspectives on Transfer in Second Language Learning. Bristol: Multilingual Matters, 2015.

COOK, V. Effects of the second language on the first. Clevedon: Multilingual Matters, 2003.

COOK, V. Second language learning and language teaching. London: Routledge, 2008.

CORDER, S. P. The significance of learners' errors. IRAL, International Review of Applied Linguistics in Language Teaching, v. 5, p. 161-170, 1967.

CORDER, S. P. Idiosyncratic dialects and error analysis. IRAL, International Review of Applied Linguistics in Language Teaching, v. 9, p. 147-159, 1971.
DE ANGELIS, G AND DEWAELE, J.-M (Ed.). New trends in Cross-Linguistic Influence and Multilingualism Research. Bristol: Multilingual Matters, 2011.

DE BOT, K. Second language learning. London: Routledge, 2006.

ELLIS, R. Second language acquisition. USA: Oxford University Press, 1997.

GABRYŚ-BARKER, D. (Ed.). Cross-Linguistics Influences in Multilingual Language Acquistion, Second Language Learning and Teaching. Berlin: Springer, 2012.

GASS, M. S.; BEHNEY, J. Second Language Acquisition. London: Routledge, 2013.

GUO, CH-J. Yousheng siwei fa. Beijing: Foreign Language Teaching and Research Press, 2007.

HAMMARBERG, B. Processes in Third Language Acquistion. Edinburgh: Edinburgh University Press, 2009.

HU, G-SH. Guoji huiyi jiaoliu. Beijing: Foreign Language Teaching and Research Press, 2013.

ISHIHARA, N. Teaching and learning pragmatics: Where language and culture meet. London: Longman, 2010.

JAMES, C. The exculpation of contrastive linguistics. In NICKEL, G. (Ed.). Papers in Contrastive Linguistics, Cambridge: CUP, 1971. p. 53-68.

LARSEN-FREEMAN, D. Teaching language: from grammar to grammaring. UK: Heinle ELT, 2003.

LADO, R. Linguistics Across Cultures. Ann Arbor, MI: University of Michigan Press, 1957.

LIGHTBOWN, P.; SPADA, N. How languages are learned. USA: Oxford University Press, 2013.

LITTLEMORE, J. Applying cognitive linguistics to second language learning and teaching. Hampshire: Palgrave Macmillan, 2009.

NITSCHKE, S. First language transfer and long-term structural priming in comprehension. Language and Cognitive Processes, v. 25, p. $94-114,2010$.

ORTEGA, L. Understanding second language acquistion. London: Routledge, 2008.

PARADIS, M. Declarative and Procedural Determinants of Second Languages (Studies in Bilingualism 40). Amsterdam: John Benjamins, 2009.

PASQUARELLA, A. Cross-language transfer of morphological awareness in Chinese-English bilinguals. Journal of Research in Reading, v. 34, p. 23-42, 2011.

SCOTT, M. WordSmith Tools. Versão 5.0. Oxford: Oxford University Press, 2010.

SHAROFF, S. ParaConc. http://www.athel.com/para.html.

SINGLETON, D. Multilingual lexical operations. In AYOUN, D.; DEKEYSER, B. (Ed.). Third Language Acquisition in Adulthood. Amsterdam/Philadelphia: John Benjamins, 2012. p. 95-113.

SINGLETON, D. Cross-lexical interaction and the structure of the Mental Lexicon. In: YU, L.; ODLIN, T. (Ed.). New 
Perspectives on Transfer in Second Language Learning. Bristol: Multilingual Matters, 2015.

SUN, Y-Q. Hedgings em textos acadêmicos: uma perspectiva de aquisição de L3. Unpublished doctoral dissertation, PUCRS, 2015.

YU, M-CH. Learning how to read situation and know what is the right thing to say or do in an L2: A study of socio-cultural competence and language transfer. Journal of Pragmatics, v. 43, p. 1127-1147, 2011.

YU, L-M. Shuangyu jiaoyulun: jianada jinrushi jiaoyu dui woguo gaoxiao shuangyu jiaoyu de qishi. Beijing: Foreign Language Teaching and Research Press, 2009.
VILDOMEC, V. Multilingualism. Leiden: A. W. Sythoff, 1963.

WANG, L-D. Yingyu kouyi zonghe nengli. Beijing: Foreign Languages Press, 2009.

WANG, W-Y. Muyu siwei yu eryu xide: huigu yu sikao. Foreign Language World, v. 4, p. 71-76, 2002.

WEN, Q-F. Yingyu jiaoxue yanjiu fangfa yu anli fenxi. Beijing: Foreign Language Teaching and Research Press, 2011.

Recebido: 12 de março de 2017

Aprovado: 24 de maio de 2017

Contato:

Sun Yuqi<yqsun@must.edu.mo> 